\title{
A Genesis of Carbonatitic Melt Within Subducting Oceanic Crusts: High-PresSURE EXPERIMENTS IN THE SYSTEM MORB-CaCO
}

\author{
Miki Shirasaka ${ }^{1, *}$ and Eiichi Takahashi ${ }^{1}$ \\ ${ }^{1}$ Tokyo Institute of Technology, Japan; * Kanazawa University, Japan
}

\section{INTRODUCTION}

In the convergent plate margin, some carbonate sediments accrete to the continental crust, and at least some of them subduct into the upper mantle. What is the fate of the subducted carbonate in the mantle? The possible link between carabonatitic melt and subducted carbonate has been paid much attention in recent literatures. Some metasomatic agent is considered to have originated from recycle carbonates in the arc system (Papua New Gu inea; McInnes and Cameron 1994) and in hot spot (Hauri et al. 1993). Hoernle et al. (2002) discussed that the carbonatite magma in the Cape Verde Islands originated from the subducted carbonate sediments.

\section{PREVIOUS EXPERIMENTAL STUDIES IN THE BASALTCARBONATE SYSTEM}

Although the role of carbonate in mantle eclogite is very important, earlier experiments have been carried out at $<3 \mathrm{GPa}$ for carbonate-bearing eclogite. Yaxley and Green (1994) and Shirasaka (1998) studied highpressure phase relations in the system $\mathrm{MORB}-\mathrm{CaCO}_{3}-$ $\mathrm{H}_{2} \mathrm{O}$ at $<3.0 \mathrm{GPa}$ and $<2.5 \mathrm{GPa}$ respectively. These experiments showed that calcite or dolomite coexists with silicate melt of andesite to dacitie compositions at relatively lower temperatures.

Yaxley (1999) carried out the partial melting of carbonated eclogite at 3 and $3.5 \mathrm{GPa}$, the first melt coexisting with calcite is carbonatitic. Shirasaka and Takahashi (in preparation) conducted high-pressure experiments on carbonated eclogite system, up to $8 \mathrm{GPa}$ with lesser carbonate contents in bulk composition than Yaxley's study (1999). The following three important results were obtained in our previous work; (1) solidus shape with a cusp at around $5 \mathrm{GPa}$ (see Fig.2), (2) Carich dolomitic to calcitic melt compositions sbove 3.5 $\mathrm{GPa}$, and (3) carbonate phase changes from calcite to dolomite, and finally aragonite + magnesite

Production of carbonatitic melt by partial melting of carbonated eclogite has been recognized. However, no experimental study has been carried out at pressures higher than dolomite breakdown at solidus. This study investigates the solidus temperature and melt compositions in the pressure range 12 to $15 \mathrm{GPa}$ where dolomite becomes unstable in eclogite system.

\section{EXPERIMENTAL PROCEDURES}

The details of experimental and analytical procedures of this study are described in Shirasaka and Takahashi (in preparation), and here we present the outlines and pertinent to the present experiment. The high-pressure experiments conducted with the mixture of $90 \mathrm{wt} \%$ of the MORB glass and $10 \mathrm{wt} \%$ of high purity $\mathrm{CaCO}_{3}$ powder.

High-pressure experiments below 3.5 GPa were carried out with a Boyd-England type piston-cylinder apparatus at the Magma Factory, Tokyo Institute of Technology (TITECH). Experiments at > 4.0 GPa were conducted using a multianvil apparatus SPI 1000 at the Magma Factory (Takahashi et al. 1993). Experiments at 12-15 $\mathrm{GPa}$ were conducted with $\mathrm{MgO}$ octahedral of $10 \mathrm{~mm}$ edge length (10M) and WC cubes with $5 \mathrm{~mm}$ truncations. Details of the cell assembly in other PT condition were described in Shirasaka and Takahashi (in preparation).

The capsule was mounted in epoxy resin and polished under ethanol. The surface of the charge was polished with diamond and coated with carbon. The compositions of all phases were determined by a wavelength dispersive electron microprobe analyzer (JEOL JXA 8800) in TITECH. All phases were analyzed with a focused beam using an acceleration voltage of $15 \mathrm{kV}$ and a beam current of $12 \mathrm{nA}$.

\section{EXPERIMENTAL RESULTS}

At 12-15 GPa, Clinopyroxene (Cpx), garnet (Grt), stishovite (St), rutile (Rt), melt and $\mathrm{CO}_{2}$ (vapor, V) are present in all runs. Additionally, magnesite (Mgs) is present. Based on experimental results and previous studies, we draw ACF-grids (Fig. 1). Phase relations in the system 90 wt.\% MORB-10 wt. $\% \mathrm{CaCO}_{3}$ at 2.7-15 $\mathrm{GPa}$ are given in Fig. 1b. Some reactions in ACF-grids (Fig. 1) apply to phase relations (Fig. 2). 


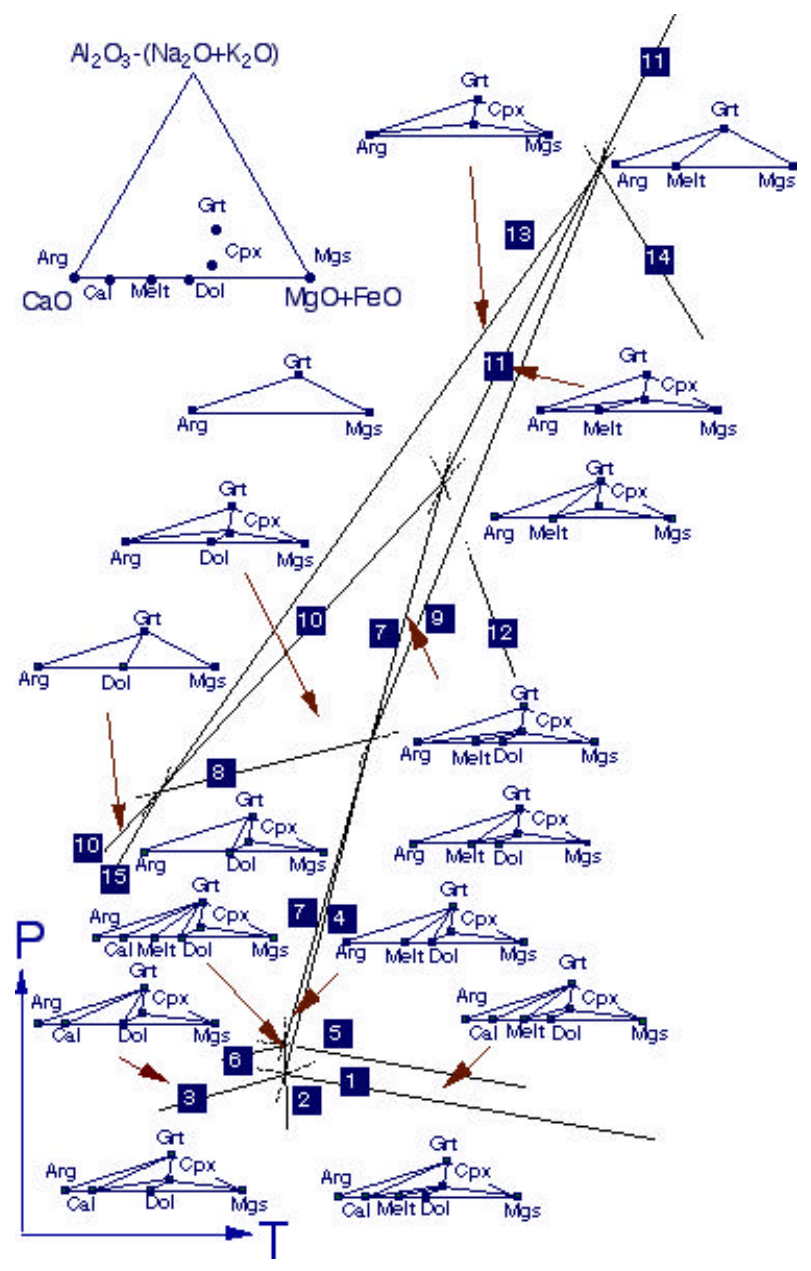

Figure 1: The grids in ternary systems in $\mathrm{A}_{2} \mathrm{O}_{3}-\left(\mathrm{Na}_{2} \mathrm{O}+\right.$ $\left.\mathrm{K}_{2} \mathrm{O}\right)$ \}/2-CaO- $(\mathrm{MgO}+\mathrm{FeO})$ saturated in $\mathrm{SiO}_{2}, \mathrm{TiO}_{2}$ and $\mathrm{CO}_{2}$. Numbers of lines mean following reaction, which shift to right with increasing temperatures;; (1) $\mathrm{Cpx}+\mathrm{Cal}=\mathrm{Grt}+\mathrm{Melt}$, (2) $\mathrm{Dol}+\mathrm{Cal}=\mathrm{Melt},(3) \mathrm{Grt}+\mathrm{Dol}=\mathrm{Cpx}+\mathrm{Cal}$, (4) Grt+Dol = Cpx+Melt, (5) Cal = Arg+Melt, (6) Arg+Dol = Cal, (7) Dol+Arg = Melt, (8) Cpx+Arg = Grt+Dol, (9) $\mathrm{Cpx}+\mathrm{Arg}=$ Grt+Melt, (10) Arg+Mgs = Dol, (11) Arg+Mgs = Melt, (12) Dol = Mgs+Melt, (13) Grt+Arg+Mgs = Cpx, (14) Cpx = Grt+Mgs+Melt, (15) Grt+Dol+Mgs = Cpx

\section{ACF-GRIDS}

This study uses ACF-grids, which are saturated in $\mathrm{SiO}_{2}$, $\mathrm{TiO}_{2}$ and $\mathrm{CO}_{2}$. Trace amounts of $\mathrm{MnO}$ and $\mathrm{P}_{2} \mathrm{O}_{5}$ are disregarded. Sodium and potassium oxides are subtracted from aluminum oxide in order to examine reactions using Tschermakite (not jadite) component in clinopyroxene. Existing phases, Grt, Cpx, Arg, Cal, Dol, Mgs and Melt, in this ACF-grids are solid solutions, and then all reactions form divaliant fields.

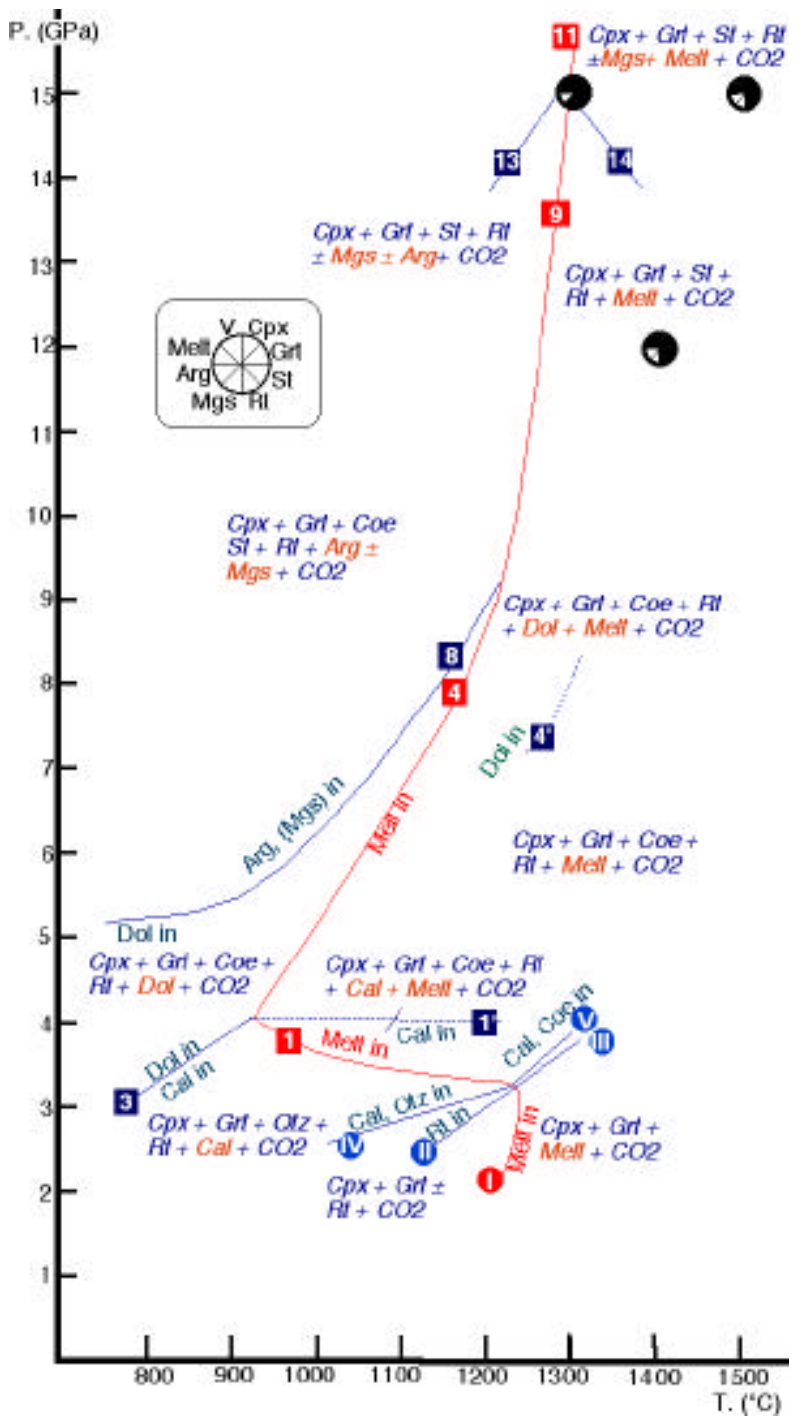

Figure 2: Phase relations in the system $90 \mathrm{wt} \%$ MORB-10 wt $\% \mathrm{CaCO}_{3}$. The solid sectors in the symbols indicate the presence of those particular phases. Arabic numbers of lines mean the reaction in Fig 1. Roman Numbers of lines mean following reactions, which shift to right with increasing temperatures; (I) $\mathrm{Cpx}+\mathrm{Grt}=$ Melt, (II) Rt dissolves in Cpx, (III) Rt dissolves in Melt, (IV) Cal and Qtz dissolve in Cpx and/or Grt, (V) Cal and Coe dissolve in Cpx, Grt and/or Melt (Details in Shirasaka and Takahashi in preparation).

Relative arrangements of the divariant reactions are decided to satisfy the following criteria; Arg at higher pressure than $\mathrm{Cal}$, assemblage $\mathrm{Arg}+\mathrm{Mgs}$ at higher pressure than Dol, and melting of $\mathrm{Mgs}$ at higher temperature than $\mathrm{Cal}$, Arg or Dol. We supplemented carbonate-grids (Arg-Cal-Melt-Dol and Arg-MeltDol-Mgs) for the $\mathrm{CaCO}_{3}-\mathrm{MgCO}_{3}$ system with the ACF-grids. 
The formation of magnesian calcite from aragonite and dolomite was studied experimentally up to $2.2 \mathrm{GPa}$ by Goldsmith and Newton (1969). It is not proved that the reaction 6 takes place at pressures higher than the invariant point (Grt, Cpx, Cal, Dol, Melt). If the reaction 6 occurs at lower pressure than this point, reactions 3 and 6, 1 and 5 overlap each other.

According to these ACF-grid analyses, magnesitebearing eclogite is stable in extensive PT field. Whereas the stable area of other carbonate phases or melt is limited. With increasing pressure, calcite changes to dolomite, and lastly to aragonite (or magnesite).

\section{Phase Relations in the system 90 WT\% MORB-10 $\mathrm{WT}_{\mathrm{C}} \mathrm{CaCO}_{3}$}

The carbonate undersaturated solidus up to $\sim 3 \mathrm{GPa}$ (the reaction $\mathrm{I}$; $\mathrm{Cpx}+\mathrm{Grt}=$ Melt) has a positive Clapeyron slope. The solidus temperature decreases from $\sim 1200^{\circ} \mathrm{C}$ at $\sim 3 \mathrm{GPa}$ to $\sim 950^{\circ} \mathrm{C}$ at $\sim 4.5 \mathrm{GPa}$ (the reaction 1 ; $\mathrm{Cpx}$ $+\mathrm{Cal}=\mathrm{Grt}+$ Melt) dramatically due to the appearance of dolomite below solidus. At 3.5-4.0 GPa, calcite is stable in solidus. With increasing pressure, dolomite is stable in solidus and carbonatitic melt is produced above ca. 4.5 GPa, and then, dolomite saturated solidus temperature increase up to ca. $1250^{\circ} \mathrm{C}$ with pressure (the reaction 4; Grt + Dol $=\mathrm{Cpx}+\mathrm{Melt}$ ). Aragonite appears in the solidus at higher pressure than dolomite dissolution (the reaction 9). At $15 \mathrm{GPa}$, solidus temperature is below $1300^{\circ} \mathrm{C}$. Then, the Clapeyron slope of solidus is gentle at pressures from 8 to $15 \mathrm{~Pa}$.

On the other hand, dolomite breaks down to aragonite + magnesite under subsolidus conditions above $5.5 \mathrm{GPa}$ (Luth 2001, Shirasaka et al. 2002). Some runs show the phase assemblage Grt + Cpx + Arg + Mgs in this study, however there are no fields on the ACF grids that theses four phases coexist except for those on the divaliant reaction 13. It is also possible that aragonite or magnesite is metastable in this run produt, or different sets of carbonate appeared due to the fluctuation of the local bulk chemistry.

\section{MELT COMPOSITIONS}

Melt above $3.5 \mathrm{GPa}$ has calcic-dolomite to calcitic composition and is low in $\mathrm{SiO}_{2}, \mathrm{TiO}_{2}, \mathrm{Al}_{2} \mathrm{O}_{3}, \mathrm{Na}_{2} \mathrm{O}$ and $\mathrm{K}_{2} \mathrm{O}$ contents. The solidus melt composition is strongly influenced the carbonate phase stable at solidus. Melt of calcite saturated solidus is magnesian calcitic composition. Ca-rich dolomitic melt appears at dolomite saturated solidus. Above $3.5 \mathrm{GPa}$, melt becomes in more calcitic composition with increasing temperature. At solidus of $15 \mathrm{GPa}$, melt coexists with aragonite and/or magnesite. At $15 \mathrm{GPa}$, dolomitic melt is produced at $1300^{\circ} \mathrm{C}$. At $1500^{\circ} \mathrm{C}$, melt is calcitic composition.

\section{DISCUSSIONS}

\section{COMPARISON WITH EXPERIMENTAL STUDIES FOR CARBONATED PERIDOTITES}

Over the past few decades, a considerable number of studies have been conducted on high-pressure experiments in the system peridotite- $\mathrm{CO}_{2}$. Carbonate phase is dolomite or magnesite at pressures above an invariant point (Fo-En-Di-Dol-Melt, 2.7 GPa) in the lherzolite- $\mathrm{CO}_{2}$ system. The experimental study of anhydrous peridotite- $\mathrm{CO}_{2}$ system (Dalton and Presnall 1998) showed that the carbonate-saturated solidus has a positive Clapeyron slope, and is $1430^{\circ} \mathrm{C}$ at $7 \mathrm{GPa}$. Extrapolated their peridotite- $\mathrm{CO}_{2}$ solidus to $15 \mathrm{GPa}$ is higher in temperature than that of the present study. Melt composition in the lherzolite- $\mathrm{CO}_{2}$ system is dolomitic or more magnesite-rich, and there is no condition to yield calcitic melt.

Partial melting of carbonated wehrlite at pressures below the invariant point may produce calcitic melt. For example, Dalton and Wood (1993) showed that Cacarbonatitic melt is present in wehrlite. On the other hand, in the eclogite- $\mathrm{CO}_{2}$ system, calcitic melt occurs at solidus of $\sim 3.5 \mathrm{GPa}$. Moreover, at temperatures higher $\sim 100^{\circ} \mathrm{C}$ than solidus in very wide pressures of $4.5-15$ $\mathrm{GPa}$, calcitic melt coexists with eclogite.

\section{GENESIS OF CARBONATITIC MELT IN SUBDUCTION ZONES}

Shirasaka and Takahashi (in preparation) showed that, in the subduction zone with relatively cold oceanic lithosphere with carbonated sediments, carbonate is stable at least up to $8 \mathrm{GPa}$. Based on the present study, behavior of carbonate in deeper subducted slabs can be discussed. Peacock et al. (1994) calculated geotherms on the surface of slab. The calculated geotherm for 50 Ma old slab crosses the carbonated eclogite solidus in the present study at $\sim 15 \mathrm{GPa}$. There is a possibility that carbonated eclogite produces carbonatitic melt under various depth conditions in the upper mantle, because the solidus has a small Clapeyron slope and the cross over could take place over a wide pressure range. The melt composition forrmed along the solidus is dolomitic to calcitic, and then a Ca-rich carbonatitic melt would metasomatize mantle peridotite. 


\section{REFERENCES}

Dalton, J.A., Presnall, D.C., 1998. Carbonatitic melts along the solidus of the model lherzolite in the system $\mathrm{CaO}-$ $\mathrm{MgO}-\mathrm{Al}_{2} \mathrm{O}_{3}-\mathrm{SiO}_{2}-\mathrm{CO}_{2}$ from 3 to $7 \mathrm{GPa}$. Contrib. Mineral. Petrol. 131, 123-135.

Dalton, J.A., Wood, B.J., 1993. The compositions of primary carbonate melts and their evolution through wallrock reaction in the mantle. Earth Planet. Sci. Lett. 119, 511-525.

Goldsmith, J.R., Newton, R.C., 1969. $P-T-X$ relations in the system $\mathrm{CaCO}_{3}-\mathrm{MgCO}_{3}$ at high temperatures and pressures. Am. J. Sci. 267A, 160-190.

Hauri, E.H., Shimizu, N., Dieu, J.J., Hart, S.R., 1993. Evidence for hotspot-related carbonatite metasomatism in the oceanic upper mantle. Nature $365,221-227$.

Hoernle, K., Tilton, G., Le Bas, M.J., Duggen, S., GrabeSchöberg, D., 2002. Geochemistry of oceanic carbonatites compared with continental carbonates: mantle recycling of oceanic carbonate. Contrib. Mineral. Petrol. 142, 520-542

Luth, R. W., 2001. Experimental determination of the reaction aragonite + magnesite $=$ dolomite at 5 to $9 \mathrm{GPa}$. Contrib. Mineral. Petrol. 141, 222-232

McInnes, B.I.A., Cameron, E.M., 1994. Carbonated, alkaline hybridizing melts from a sub-arc environment: mantle wedge samples from the Tabar-Lihir-Tanga-Feni arc, Papua New Guinea. Earth. Planet. Sci. Lett. 122, 125141.

Peacock, S.M., Rushmer, T., Thompson, A.B., 1994. Partial melting of subducting oceanic crust. Earth Planet. Sci. Lett. 121, 227-244.

Shirasaka, M., 1998. High-pressure phase equilibrium in the system MORB- $\mathrm{H}_{2} \mathrm{O}-\mathrm{CaCO}_{3}$ : a role of $\mathrm{CO}_{2}$ in subduction zone. Master thesis, Yokohama National Univ. Yokohama, Japan

Shirasaka, M., Takahashi, E., in preparation, A fate of subducted carbonate within slab: high-pressure experiments in the system $90 \mathrm{wt} \%$ MORB-10 wt $\%$ $\mathrm{CaCO}_{3}$.

Shirasaka, M., Takahahi, E., Nishhara, Y., Matsukage, K., Kikegawa, T., 2002. In situ X-ray observation of the reaction dolomite $=$ aragonite + magnesite at 900 1300 K. Am. Mineral. 87, 922-930.

Takahashi, E., Shimazaki, T., Tsuzuki, Y., Yoshida, H., 1993. Melting study of a peridotite KLB-1 to $6.5 \mathrm{GPa}$, and the origin of basaltic magmas. Phil. Trans. R. Soc. London. A 342, 105-120.

Yaxley, G.M. 1999. Phase relations of carbonated eclogite under upper mantle PT conditions - implications for carbonatite petrogenesis. The proc. 7th international kimberlite conf. pp. 933-939

Yaxley, G.M., Green, D.H., 1994. Experimental demonstration of re fractory carbonate-bearing eclogite and siliceous melt in the subduction regime. Earth Planet. Sci. Lett. 128, 313-325

Contact: M Shirasaka, Kakuma-machi, Kanazawa, Japan,

920-1192, E-mail: mshira@ earrh.s.kanazawa-u.ac.jp 